\title{
Eligibility Study on Floating Solar Panel Installation over Brackish Water in Sungsang, South Sumatra
}

\author{
Andri Agus Sasmanto1, Tresna Dewi², Rusdianasari ${ }^{3}$ \\ Applied Master of Renewable Energy Engineering1 \\ Department of Electrical Engineering2 \\ Department of Renewable Energy Engineering 3 \\ Politeknik Negeri Sriwijaya \\ Jalan Srijaya Negara, Palembang, 30139, Indonesia \\ PT PLN Persero Distribution Control Center, Sumatera Selatan, \\ Jambi dan Bengkulu ${ }^{1}$ \\ Jalan Gub. H. A. Bastari, Jakabaring, Palembang, 30257, Indonesia \\ Email: andri.agus@pln.co.id, \{tresna_dewi, rusdianasari\}@polsri.ac.id
}

Received March 26, 2020; Revised April 6, 2020; Acccepted May 16, 2020

\begin{abstract}
Electric generation using the photovoltaic (PV) effect is considered ideal in South Sumatra as a response to the government policy to increase the utilization of renewable energy to support the depletion of conventional energy. PV panels can be installed in a fishing village in the Sungsang Estuary. This paper examined the eligibility analysis for the installation of PV panels on brackish water. In this research, two Panels are installed, the first one is floating over a water body, and the second is ground mounted as a comparison of electricity produced and efficiency. The $I_{s c}$ floating and ground mounting differ in 0.4435 A. The measured $I_{\text {load }}$ in floating PV panels is 0.3900 A higher than the ground mounting. The $V_{o c}$ measured at the floating PV panels is 0.2935 $\mathrm{V}$ higher, and the $V_{\text {load }}$ of the floating PV panel is $3.0742 \mathrm{~V}$ higher than the ground mount. The differences are due to the floating PV panel surface temperature being lower than ground mounting. Electricity generated by floating PV panels is averagely $11.89 \mathrm{~W}$ higher, and the efficiency is $4 \%$ higher than that of ground installation. This experiment also shows that PV panels can be installed over brackish water in the fishing village of Sungsang Estuary.
\end{abstract}

Keywords: brackish water, estuary, floating PV, ground mount PV, photovoltaic.

\section{INTRODUCTION}

Energy sources need to continue to develop as the population increases enormously in decades. Current conventional fossil fuels are not adequate to satisfy market demands, and fossil fuels contain the after-effect of $\mathrm{CO}^{2}$ and 
greenhouse emissions of pollution. This condition insists the government and society substitute fossil fuel with more environmentally friendly and replenishable energy sources, called renewable energy. One must not look far for these sources; they are provided mostly for free by nature, such as from the sun, wind, geothermal, hydro, and biomass. South Sumatra has a considerable amount of coal mine, where $10 \%$ of Indonesia's energy need is provided by coal [1]-[4]. However, it would only last for around 50 years. On the other hand, South Sumatra is located in the equator, where the sun shines all the years that has a high potential for solar energy utilization [5].

Although sun incidents are free, installation costs are not cheap; therefore, many factors affecting the output power and efficiency must be considered. The solar panels are susceptible to heating and shading. The temperature can reach up to $40^{\circ} \mathrm{C}$ in South Sumatra, and the surface temperature of the solar panel can reach up to $62^{\circ} \mathrm{C}$ [5]-[14].

The overheated can be overcome by installing cooling devices, passive and active devices. One effective way to reduce panels' surface temperature is by installing the PV panel on water bodies such as reservoirs, ponds, and rivers. Water vapor and wind speed can reduce the temperature and, in time, increase the energy yield up to $10 \%$. The panels installed on the water bodies are referred to as floating PV. The panels can get the incidents not only directly from the sun but also the reflected light from the water surface [15]-[19].

Solar energy is also helpful in supplying villages that are not accessible by public utilities, such as a fishing village where fishers need electricity when they are on the sea to power the fridge and lights. Fishing villages are located by the sea or brackish water [20][21]. Floating PV is an excellent alternative to solar energy utilization; however, sea or brackish water have the containment of salt in water and vapor. The salt sediment can form shading on the surface of the panel, thus reduce the produced electricity and efficiency [22].

This paper discusses the eligibility analysis for PV panels installation on brackish water in a fishing village in Sunsang Estuary, South Sumatra. In this research, two panels are used, the first is floating over a waterboard, and the other is a ground mount. Electricity produced and efficiency of both panels are compared to show the eligibility Study on Floating Solar Panel Installation over Brackish Water in Sunsang Estuary, South Sumatra.

\section{RELATED WORKS}

South Sumatra has a high potential to use solar energy as an alternative source of electricity, as presented by Yudha [2]. However, the output and efficiency of the PV system are prone to environmental effects such as temperature (discussed by [5]-[12]) and shading from various sources (presented by [13] and[14]). Overheated due to high tropical temperatures can be overcome by a cooling system. The cooling system can be passive without additional power, as discussed in Li [7], and active with the required electrical power, as applied by Harahap [8]. The most efficient cooling system is to install PV panels over water bodies to obtain a natural cooling system. The floating PV panel receives more incidents since the incidents are not only 
directly from the sun, but also the reflected ones on the water surface, as presented in [15]-[19].

PV panels would be a useful source of electricity to people living in the Sunsang Estuary. However, the installation of PV panels on brackish water has its downside, such as partial shading. Current floating PV panels are installed over freshwater, such as Cazzaniga 's integration of PV floating with a hydroelectric power plant [15]. This study, therefore, discusses the possibility of installing a floating solar panel over brackish water. This research is an extension of our research on [22], where the effect of sea salt deposition on the output and efficiency of PV panels is investigated.

\section{PROPOSED METHOD}

This paper proposed the installation of a PV panel over brackish water in Sunsang Estuary, South Sumatra. The experiment compares the output of floating to ground mounting PV panels to show the effectiveness of the proposed method.

\subsection{RELATED THEOREMS}

\subsubsection{TEMPERATURE EFFECT ON PV PANELS}

All valence electrons move around the nucleus at absolute zero temperature. Therefore, no free electrons in the conduction band that can transport electrical energy from one place to another. In this state, the semiconductor acts as the perfect insulator at this zero temperature. If the temperature of heat energy in the semiconductor increases, more valence electrons gain energy to break bonds with the nucleus and spring into the drive band. This condition increases the number of free electrons in the conductive band. When more electrons leave the valence band and enter the conduction band, there are more holes in the valence band. A small increase in heat can, therefore, produce more charge carriers (electrons and holes).

Temperature increases the atomic vibration in semiconductors. Atomic vibrations in the semiconductor affect electrons and cause many electrons to be free of fluids. As a result, the current flow in semiconductors is increased. Increased current flow means a decrease in strength. The electrical current in semiconductor increases as the temperature increases and the resistance of the semiconductor decreases with an increase in temperature.

The parameter most affected by temperature increase is the opencircuit voltage $\left(V_{o c}\right)$ in Equation 1, which is decreased due to its dependence on $I_{o}$ (the saturation current A).

$$
V_{o C}=\frac{n k T}{q} \ln \left(\frac{I_{L}}{I_{o}}+1\right),
$$

where $k$ is the Boltzmann constant $\left(1.380649 \times 10^{-23} \mathrm{~m}^{2} \mathrm{~kg} \mathrm{~s}^{-1} \mathrm{~K}^{-1}\right), n$ is diode ideality factor (the highest is 1 ), $\mathrm{T}$ is the absolute temperature $(\mathrm{K}), q$ is the electron charge $\left(1.60217646 \times 10^{-19} \mathrm{C}\right)$, and $I_{L}$ is the light generated current (A), where $I_{S c} \approx I_{L}$. 
The temperature difference between ambient temperature and PV panel's surface temperature can be modeled by

$$
T_{C}=T_{a}+k G_{R},
$$

where $T_{C}$ is the cell temperature, $T_{a}$ is the ambient temperature, $G_{R}$ is the irradiance received by the cell and $k$ is the Ross coefficient. The Ross coefficient depends on the mounting structure, i.e., the free-standing is 0.021 $\mathrm{K} . \mathrm{m}^{2} / \mathrm{W}$, the flat roof is $0.026 \mathrm{~K} . \mathrm{m}^{2} / \mathrm{W}$, sloped and the well-cooled roof is 0.020 $\mathrm{K} . \mathrm{m}^{2} / \mathrm{W}$, and the inclined highly integrated roof is $0.056 \mathrm{~K} . \mathrm{m}^{2} / \mathrm{W}$ [12].

\subsubsection{SEASALT EFFECT ON FLOATING PV PANELS}

The sea salt accumulation on the PV panel surface is related to the effect of shading and partial shading. In this case, the most likely to occur is the partial shading due to the uneven spread of sea salt sediments on the surface. The accumulation of salt from brackish waters in the solar panel has the same effect as dust and other shades, and the uneven distribution of salt dust causes some parts of the PV panel to be partially shaded. The partial shading of one part of the PV panel results in the generation of a lower amount of energy compared to the unshaded parts. The differences in the amount of Power generated between the unshaded and the shaded lead to overheating.

Figure 1 shows the condition of partial shading in which only one cell is shaded. The cells are connected in series to the shaded one; therefore, in this condition, the shaded cells block the flowing current. Unshaded cells forward bias the current, but due to the shaded cell, the current is inverted and shortcircuited. Hot spot heating occurs when the large current is reversed bias in one cell, leading to a significant dissipation of Power in the shaded cell. As a result, the entire generated Power from normal cells is dissipated in a broken PV cell. This dissipated Power causes over-heating or hot spots that can lead to reduced energy output and even physical cell destruction, such as glass cracking and cell melting. Therefore, the partial shading reduces not only energy output and efficiency but also the temperature increment lead to the possible short circuit of parts with more salt piles, leading to a cell failure of the panel. 


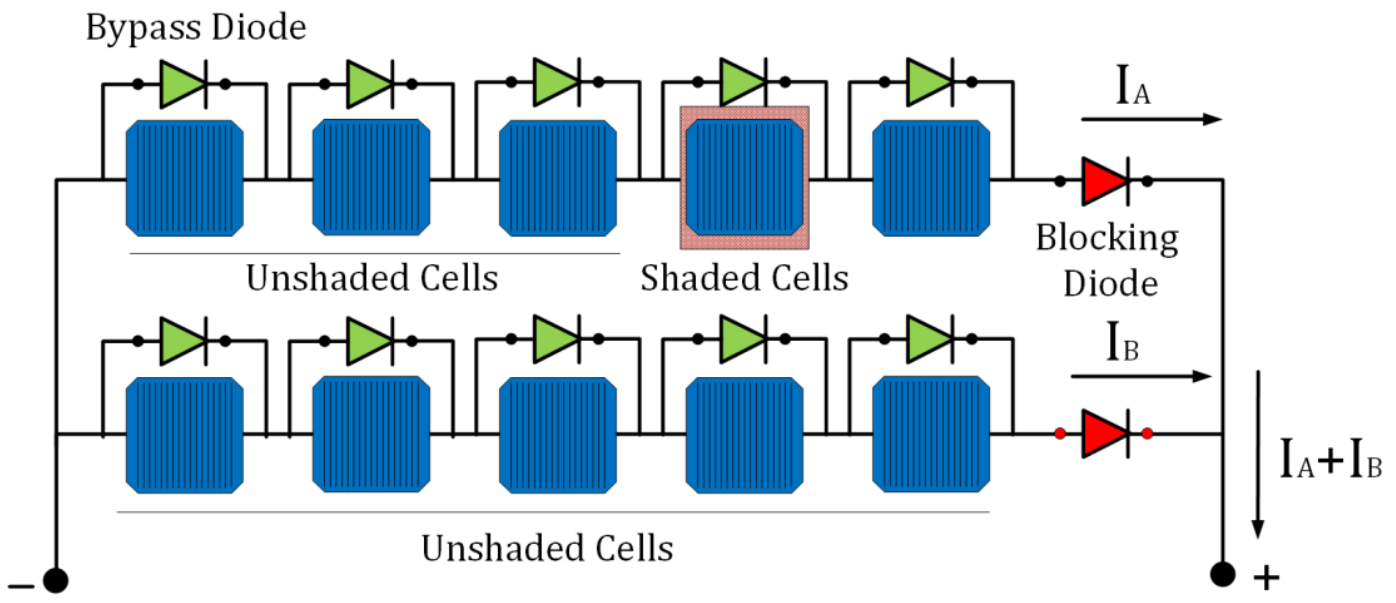

Figure 1. The illustration of shaded and unshaded PV cells.

To overcome the problem of overheating and short-circuiting due to partial shading, bypass diodes are installed, as shown in Figure 1. Bypass diode acts as a safety device to prevent damage to the entire panel. Therefore, the failure is isolated only to the shaded cell. The bypass diode is not active if two neighboring cells in the PV panel receive equal radiation. If one cell is disturbed due to overheating, the electricity flows through the bypass diode to prevent short-circuit during the working time of the PV panels. The blocking diode is installed to ensure that the electrical current flows only in one direction to the external load. PV cell in Figure 1 is modeled as an ideal diode with the circuit shown in Figure 2, and the generated current (I) is given by

$$
I=I_{p h}-I_{0}\left(e^{q\left(\frac{V+I R_{S}}{A k T}\right)}-1\right)-\frac{V+I R_{S}}{R_{S h}}
$$

where $I_{p h}$ is the photocurrent, $R_{s}$ is series resistance, $R_{s h}$ is shunt resistance, $I_{D}$ is voltage-dependent current due to recombination, and $V$ is voltage.

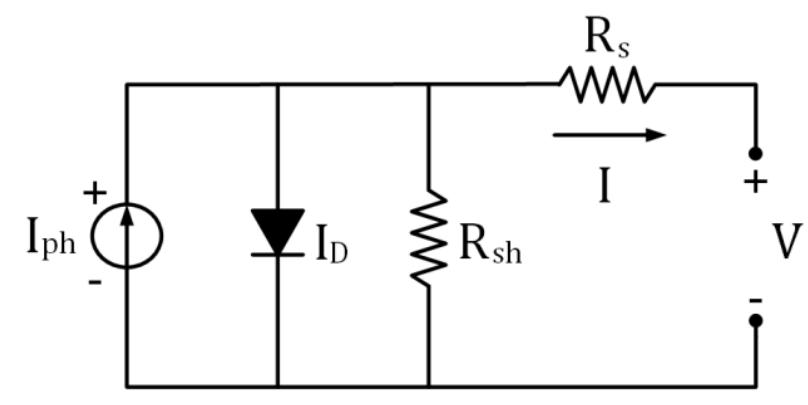

Figure 2. PV cell equivalent circuit 


\subsection{PROPOSED FLOATING PV PANELS}

Brackish water, or sometimes called brack water, is the place where the salt and freshwater mixed. Brackish water contains more salinity than freshwater but less than seawater due to the mixing of water from the river and seawater. An estuary is where the river meets the sea; therefore, the salinity of the estuary environment is changing rapidly in a short time due to tidal and monsoon. During the tidal, the amount of seawater in estuary increases, while the containment of freshwater increases with heavy precipitation. The variation can vary from 10 to $32 \%$, with average freshwater salinity $0.5 \%$ [20]. The estuary is a beneficial environment as a perfect habitat for mangrove swamps house for shrimps, crabs, and alike.

Sungsang Estuary is located near Palembang, the capital city of South Sumatra. It is where the Bangka strait and Musi river meet and are an ideal area for a high diversity of fishery nursery [21]. As illustrated in Figure 3, this estuary has been fishing ground, lodging, and transportation for the Sungsang people. The PV system installation on offshore lodging and floating it over the water bodies help to supply the electricity for fishers and increase the quality of life and work.

The salinity containment in Sunsang estuary is $20.8 \%$ lower than the saltwater. Despite the benefit solar panel installation over the waterbodies, the power output and efficiency are decreasing over time due to the accumulation of salty dust on the surface of PV panels compared to ground mount in the same area.
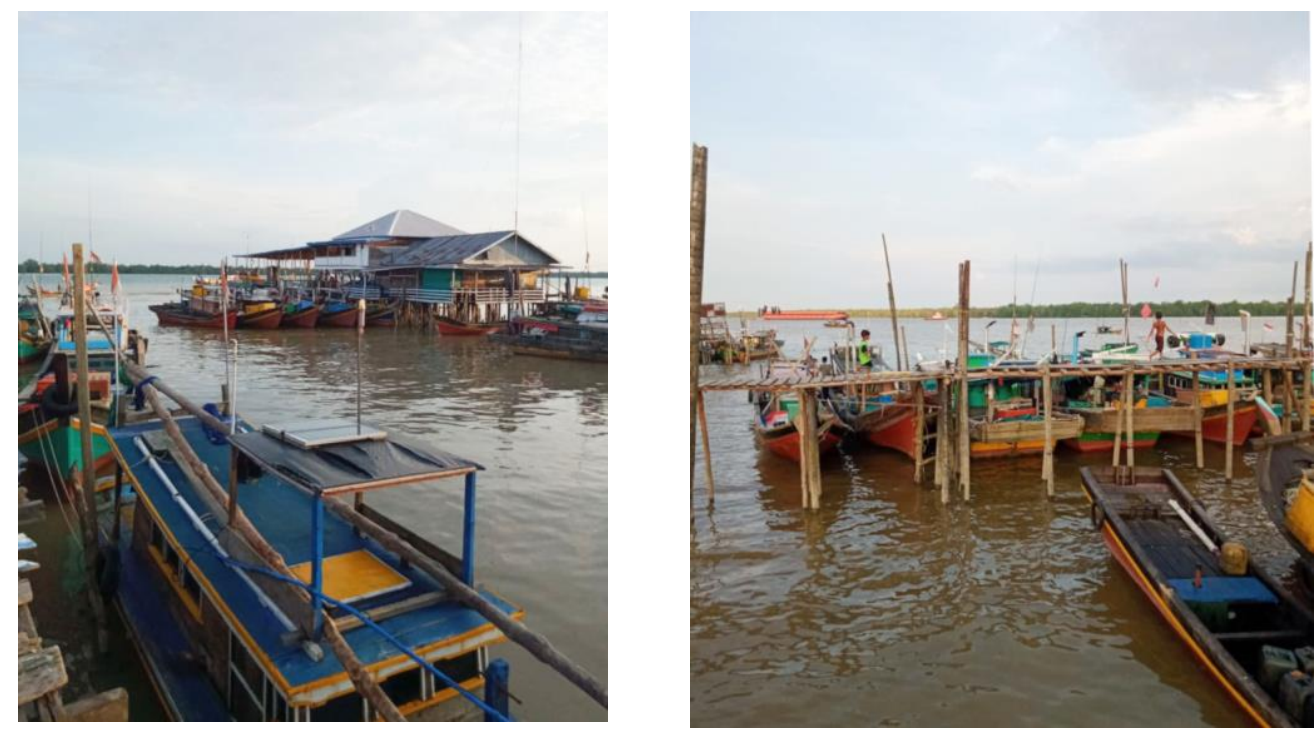

Figure 3. Sungsang estuary environment

The floating PV panels have been planned and built to float on lakes, rivers, dams, and mining ponds. This installation is a good alternative for a high-density area where land is scarce. This paper tests the idea of introducing a floating PV system brings electricity to places that can not be reached by public utilities or to a moving vehicle. This paper proposed the application of 
floating solar PV panels in Sungsang Estuary with two options, directly above water and ground mounting. The ground mounting can also be the simulation of mounting PV panels on the fisherman's boat. This study is the continuation of our work in [22].

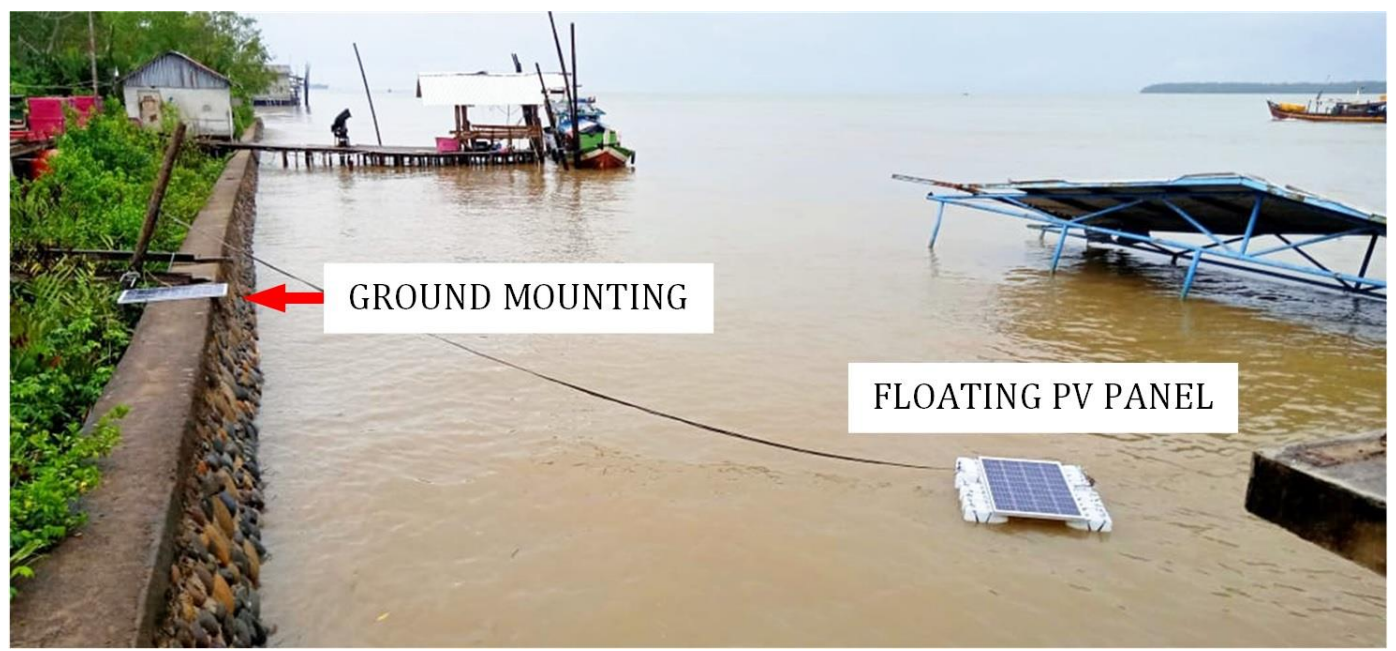

Figure 4. Floating and ground mounting PV panels.

The floating PV panel in this study is shown in Figure 4, where the electricity produced yield and efficiency are compared with ground mounting by the estuary. Figures 3 and 4 show that boats are roaming in this estuary. The ground mounting can be considered as the simulation in mounting the PV panel on the roof of the boats. This boat's roof mounting can be handy for supplying fishers with electricity.

\section{EXPERIMENT AND ANALYSIS}

\subsection{Experimental Setup}

The experiment is conducted by installing two PV panels. The PV panel utilized in this study is Polycrystalline with $100 \mathrm{Wp}$ each. One is floated in the estuary, and another one is ground mounted, as shown in figures 4 . Figure 5 shows the dimension of the floating and ground mounting PV panels. The panels were connected to Shunt resistor $100 \mathrm{Ohm}$ and 100 Watt 24 VDC lamp as the load. The arrangement and measurement setting are shown in Figure 6.

The experiment was performed from December 24th 2019 to January $24^{\text {th }} 2020$ at Sungsang IV village, Banyuasin Regency, South Sumatra. Nonetheless, on 13 January 2020, the data were not taken due to the failure of the individual to collect the data. This estuary is located in $-2^{0} 34^{\prime} 10^{\prime} \mathrm{S}$, 104 090'20E, about $83.3 \mathrm{~km}$ from Palembang, the capital of South Sumatra. The data was collected per hour from 08.00 a.m. to 05.00 p.m. every day. The salinity of Sunsang Estuary is 20.8\% lower than the seawater salinity. The precipitation is high during the experiment, which could reduce salt in the water. 

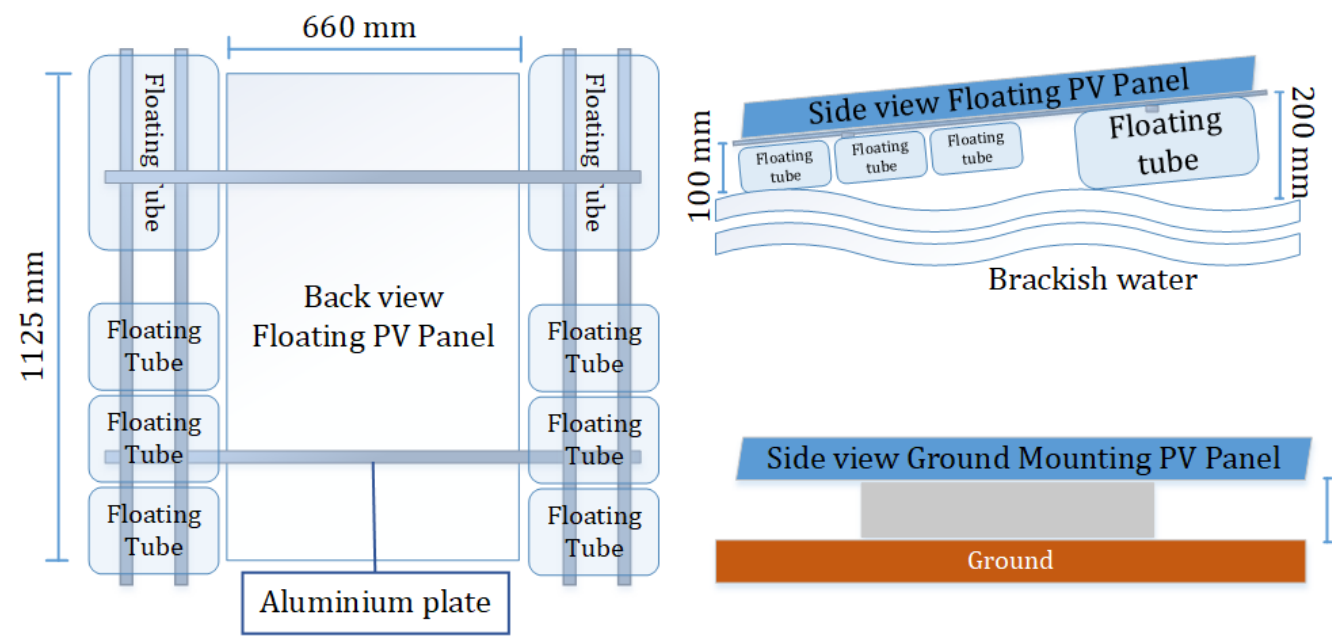

Figure 5. Floating and ground mounting PV panels dimensions.
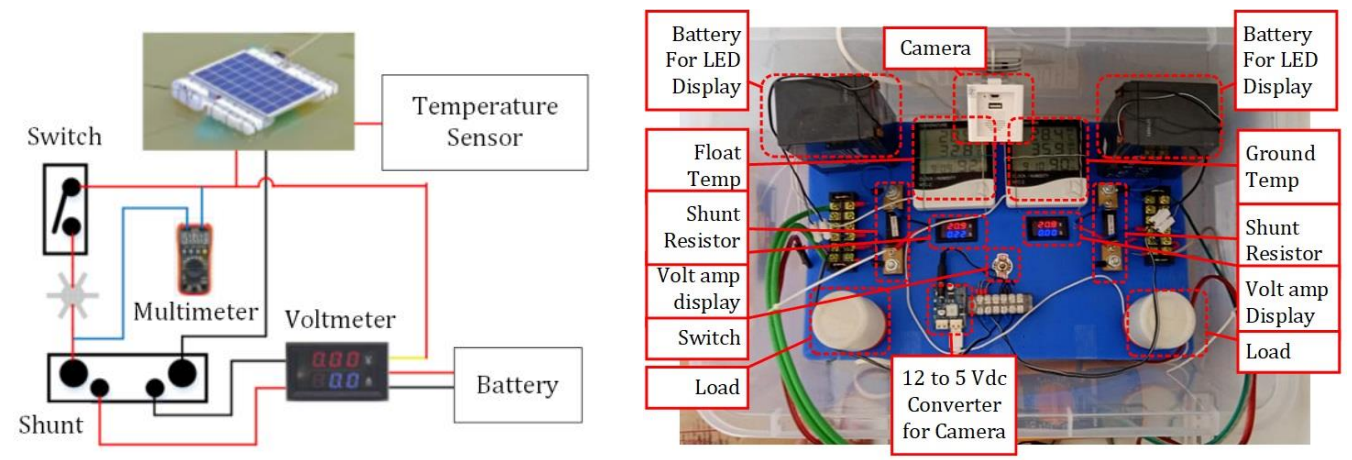

Figure 6. The measurement setting

\subsection{Experiment Results}

While the experiment was scheduled for 32 days, due to weather challenges and other cause, data was not collected as anticipated on January $13^{\text {th }}, 2020$. On December 26th, 2019, an unusual occurrence happened, the solar eclipse is apparent in most parts of Indonesia, including the Sungsang Estuary. This principle in nature is perfect for showing that it is the radiation converted to electricity, not the temperature. South Sumatra faces rainy season December and January. Therefore, the weather transition effects (sunny, cloudy, and rainy) on electricity generation can be studied.

This climate illustration is shown in Figure 7, where the weather brightness level is indicated by numbers of sunny, cloudy, and rainy hours that happened on a given date. The " 8 " level of weather brightness means there were 8 hours of sunshine out of 10 experiment hours. Therefore, weather brightness rates are "7" on 6 January 2020, because it was just seven hours of sunny weather that day. Figure 7 shows that there were 13 completely sunny days and 19 days of sunny, cloudy, and rainy variety. For December 31st, 2019, 
the weather was most unfavorable for producing electricity, as it was dominated by clouds and rains.

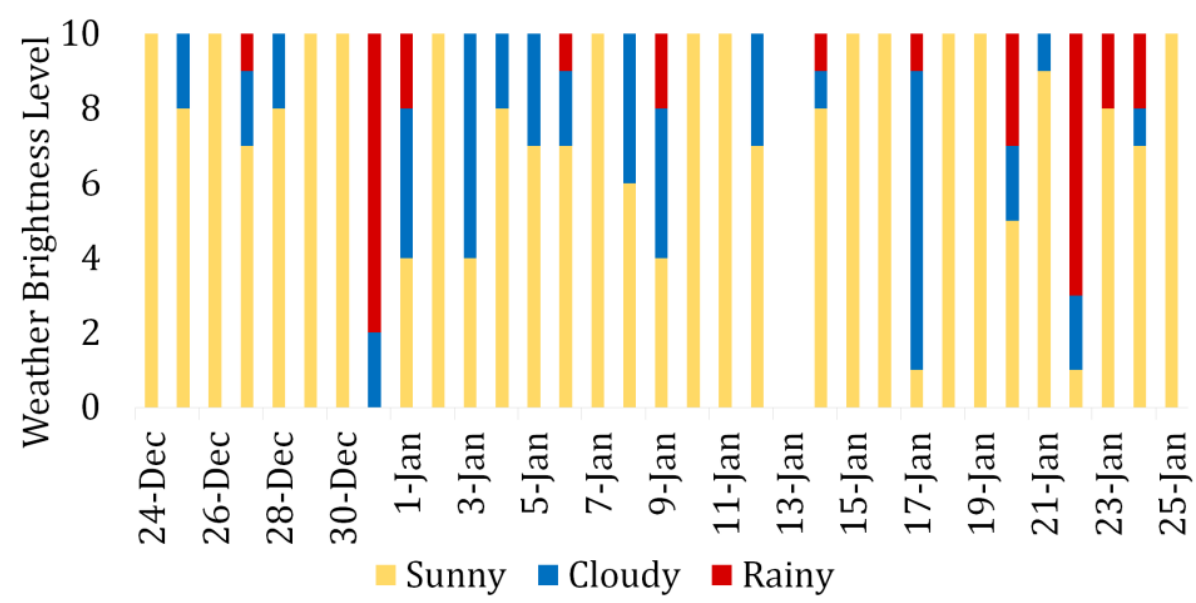

Figure 7. Weather condition during the experiment in 31 days.

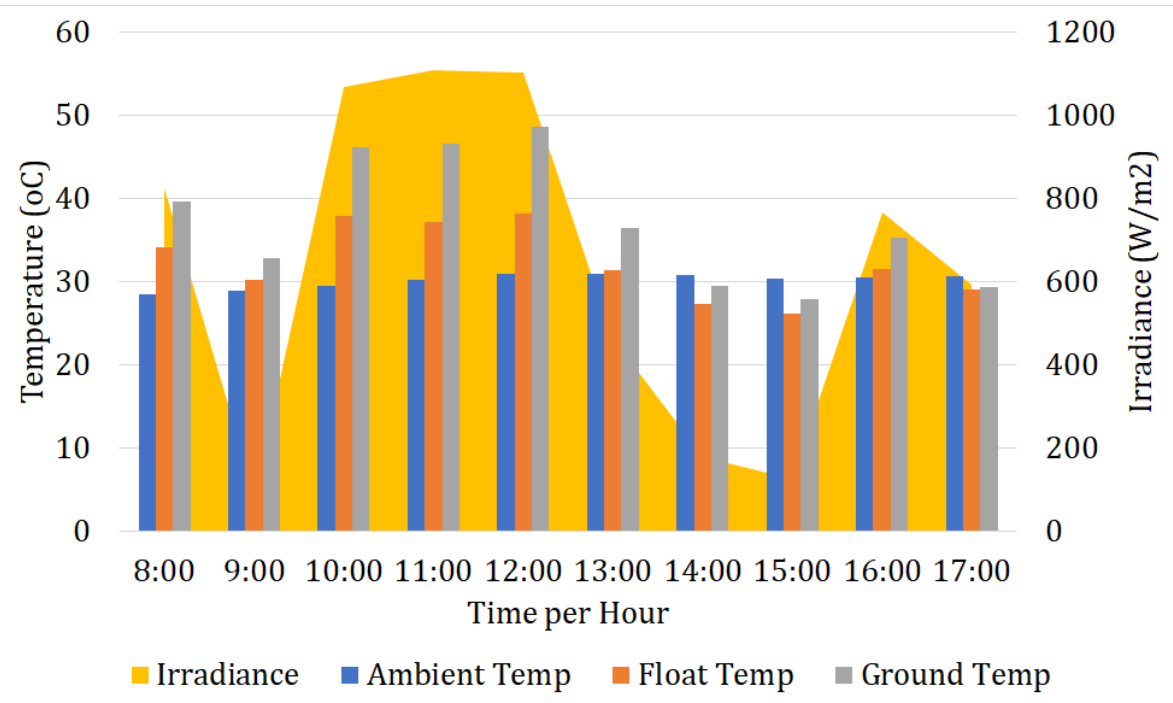

Figure 8. The comparison of Ambient temperature and PV panels' surface temperature of floating and ground mounting on January $6^{\text {th }}, 2020$.

The ambient temperature on the surface temperature of the PV panels is shown in Figure 8, where, as predicted in Equation 2, the surface temperature is higher than the environmental temperature. The water body cools down the ambient temperature below the floating PV panel resulting in the lower surface temperature of the floating mount. Figure 8 displays the oneday data result from January $6^{\text {th }}, 2020$, which is chosen due to the day's cloudy, sunny, and rainy weather adjustments. The consequences of these weather changes can, therefore, be studied. 


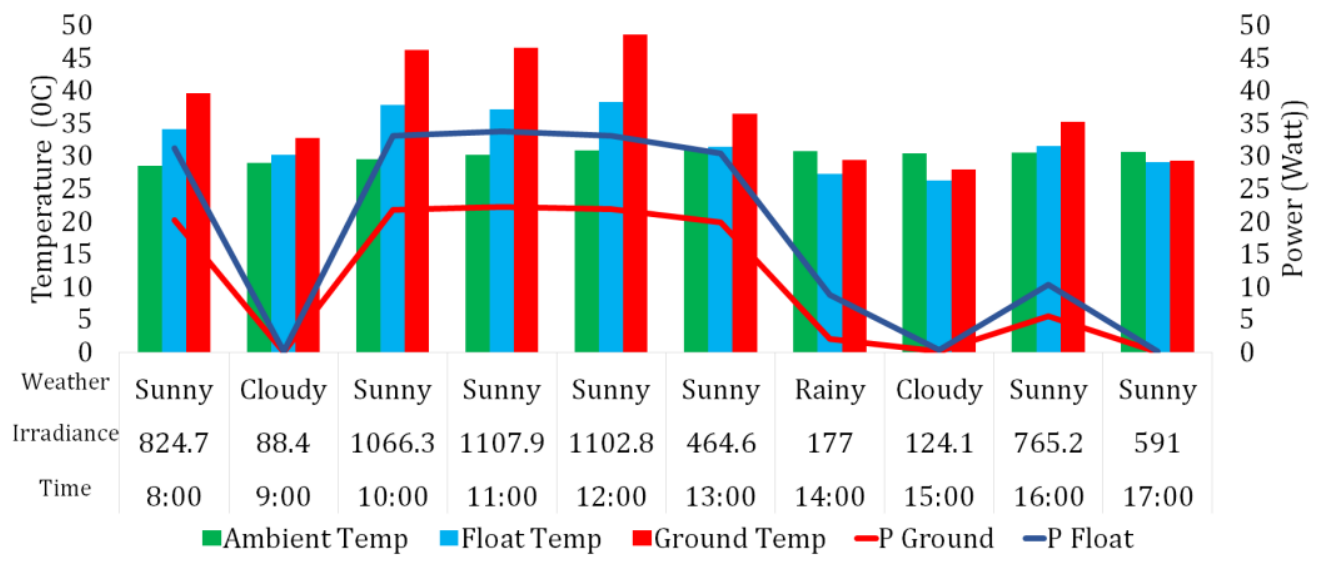

Figure 9. The produced Power relative to ambient temperature on January $6^{\text {th }}, 2020$.

The change of weather has a profound impact on the performance of the PV panel, the energy produced is high during sunny weather, and drops significantly as the sunny weather transitions into cloudy or rainy weather. This shift in energy yield is shown in Figure 9, which shows the data taken on January $6^{\text {th }}, 2020$. Figure 9 shows that the energy yield is profoundly affected by the weather condition, as this is the disadvantage of direct generation using the PV effect. The Power generated at 09.00 a.m. and 03.00 p.m. was near zero. The stable Power ranges from 10.00 a.m. to 01.00 p.m., while the Power produced during rainy hours was deficient due to cloud shading.

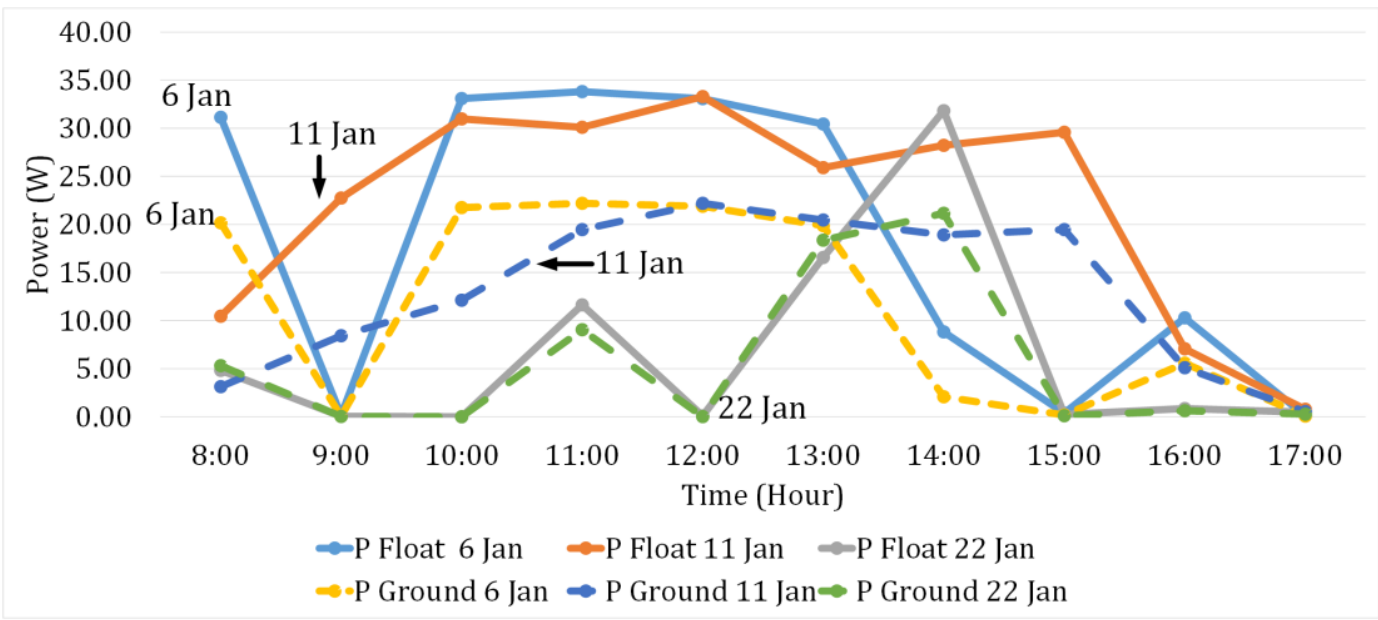

Figure 10. The Power generated on January 6th, 11th, and 22nd, 2020.

To further demonstrate the impact of the weather transition on generated electricity, the data for January $6^{\text {th }}, 2020$, is compared to all sunny days (January $11^{\text {th }}, 2020$ ) and rainy and cloudy days (January $22^{\text {nd }}, 2020$ ). The data comparison is shown in Figure 10. The full sunny day (January 11th, 2020 ) gives a stable generation of solar radiation that could be achieved by PV panels on the basis of the typical PV generation profile per hour. The generated Power increased every hour until the peak hour (10.00 a.m. to 3.00 p.m.), and 
the generated Power decreased as the solar radiation weakened. The energy generated on January $22^{\text {nd }}, 2020$, is deficient because most of the day, it was cloudy and rainy.

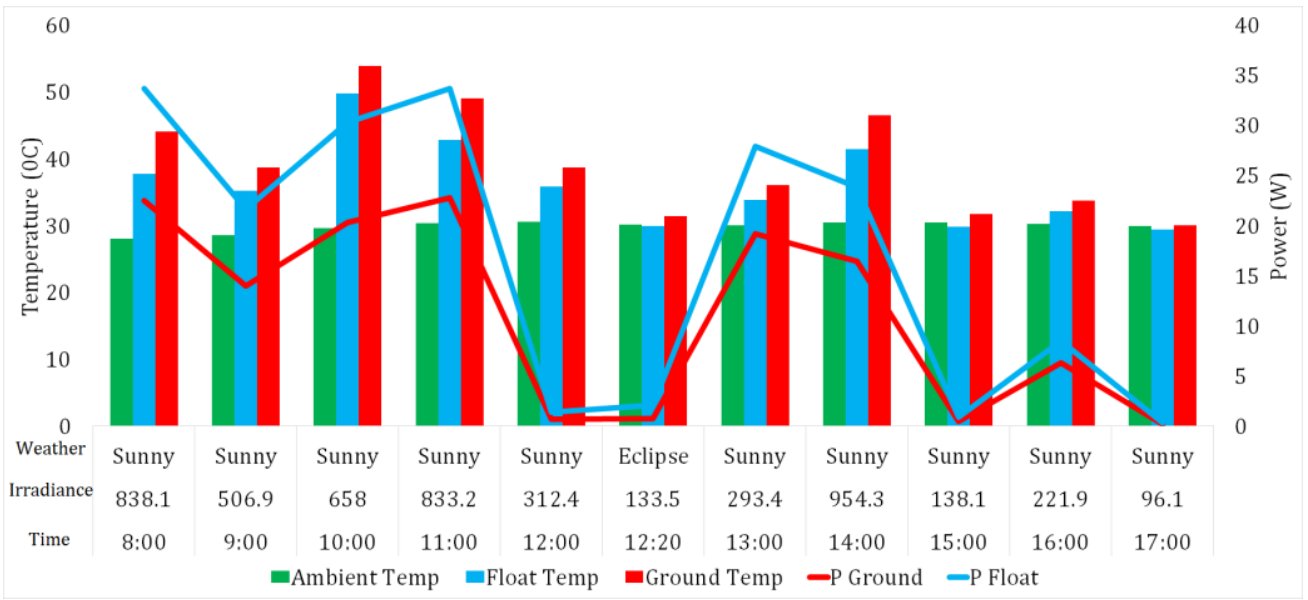

Figure 11. The produced Power relative ambient temperature during Sun Eclipse.

On December 26th, 2020, an exciting phenomenon happens, the eclipse. The energy yield decreased to near zero during the eclipse, but the weather before and after the eclipse is sunny, and the Power generated was significantly high. This variation in Power production is reflected in Figure 9.

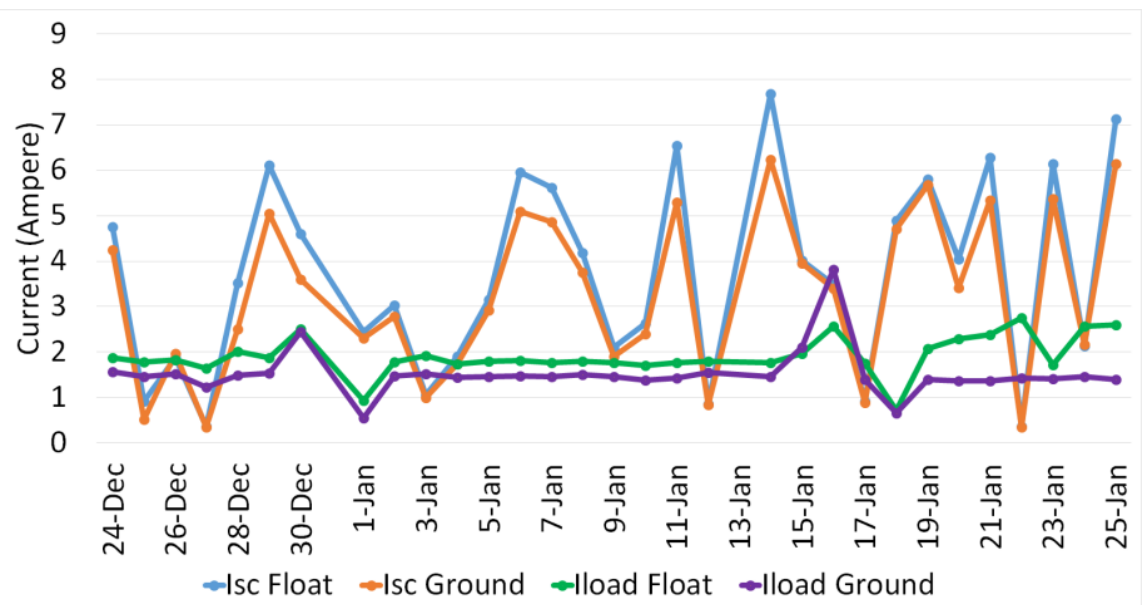

Figure 12. The generated $I_{s c}$ and $I_{\text {load }}$ floating PV and ground mounting.

Figure 12 shows the generated $I_{s c}$ (short circuit current) of floating and ground mounting PV panels. Figure 12 also shows the $I_{\text {load }}$ of floating dan ground mounting PV panels during the Panels connected to DC Lamp as the load. Figure 13 shows the comparison between the generated $V_{o c}$ of floating and ground mounting, as well as the difference between measured $V_{\text {load }}$ during the supply of DC lamp for both floating and ground mounting. $I_{s c}$ is the maximum current generated accross the panels when the voltage is zero, and 
on the other hand, $V_{o c}$ is the maximum voltage produced by the PV panels when the current is zero. These two parameters are the key component for IV-curve.

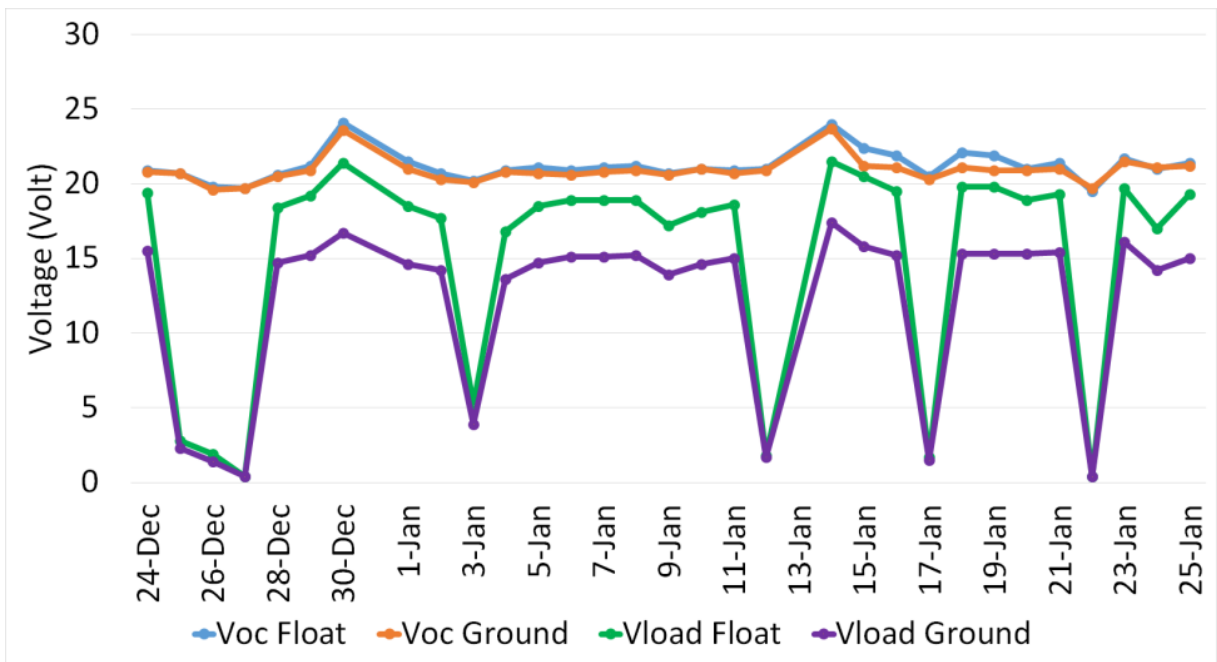

Figure 13. The produced $V_{o c}$ and $V_{\text {load }}$ of floating PV and ground mounting.

The difference between $I_{s c}$ floating and ground mounting is $0.4435 \mathrm{~A}$. The measured $I_{\text {load }}$ in floating PV panels is 0.3900 A higher then $I_{\text {load }}$ of ground mounting. The $V_{o c}$ measured at the floating PV panels is $0.2935 \mathrm{~V}$ higher than the ground mounting. The $V_{\text {load }}$ of the floating PV panel is 3.0742 $\mathrm{V}$ higher than ground mount. The difference due to the floating PV panel surface temperature is lower than ground mounting, as shown in Figure 8, and this is the proof of Equations 1.

Figure 14 shows the comparison of the maximum Power generated daily Power between floating PV panels and ground mounting. The generated Power is profoundly affected by the level of irradiance and the brightness of the weather. Thus, although the level of weather brightness was higher on 24, 26, and 29 December 2019, the maximum Power produced on those days is lower than the maximum Power achieved on January 14th, 2020. The maximum irradiance for December $24^{\text {th }}, 2019$, is $828.9 \mathrm{~W} / \mathrm{m}^{2}$, December 26 th, 2019 , is $954.3 \mathrm{~W} / \mathrm{m}^{2}$, and December 29 th, 2019, is $938 \mathrm{~W} / \mathrm{m}^{2}$. While the maximum irradiance on January 14 th, 2020 , is $1410.4 \mathrm{~W} / \mathrm{m}^{2}$. The irradiances achieved by the solar panel shown in Figure 15 is measured by Solar Power Meter. The electricity produced by floating PV panels is $11.89 \mathrm{~W}$ higher on average compared to the ground mounting. Figure 15 shows the generated power and irradiance through the experimental days, where $\mathrm{P}_{\text {Float }}$ and $\mathrm{P}_{\text {Ground }}$ are achieved by taking the highest produced power generated on a day. 


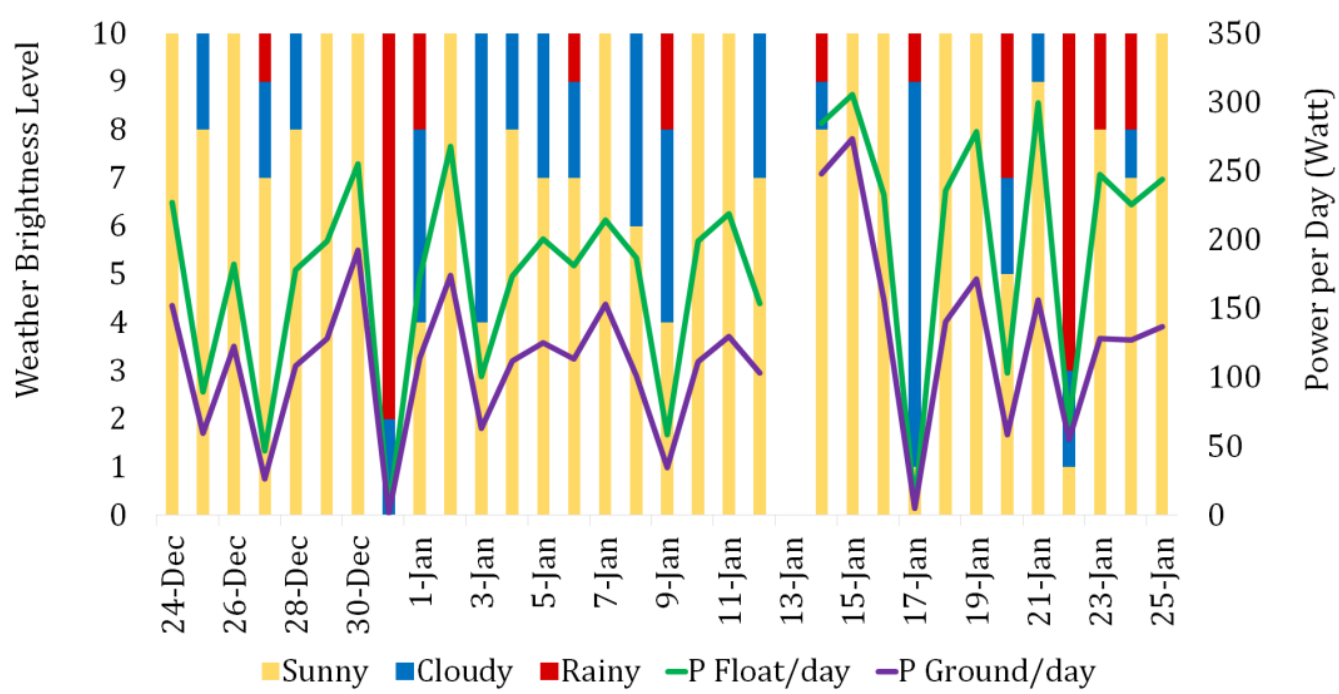

Figure 14. The comparison of the generated power of float PV panels and ground mount per day.

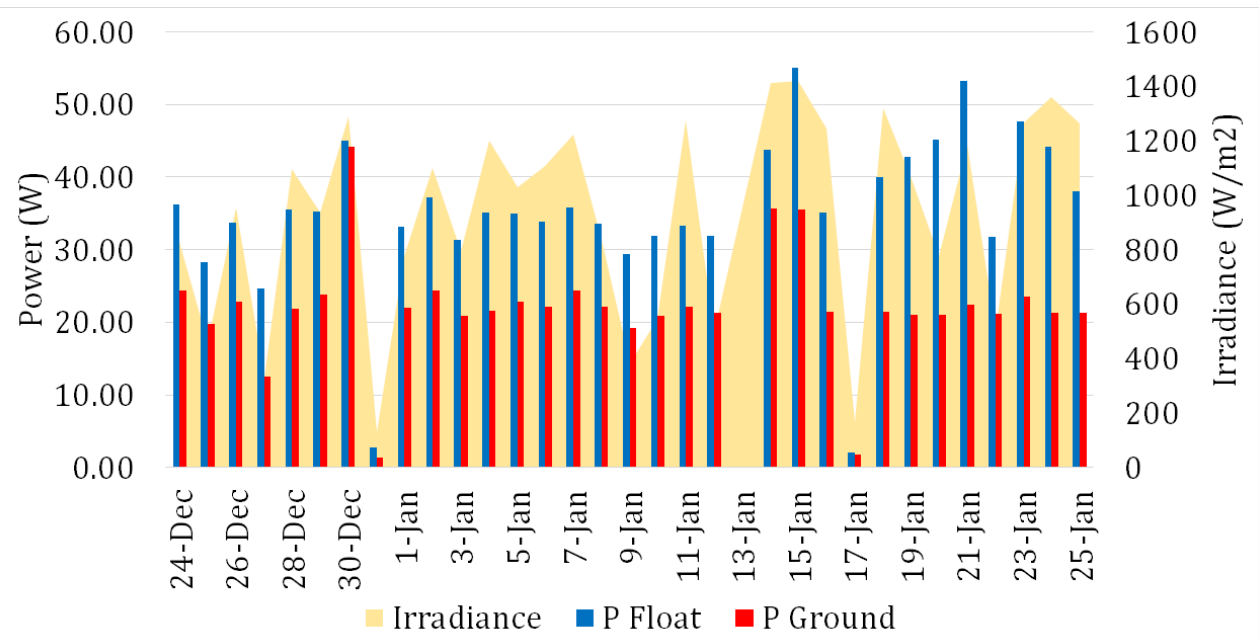

Figure 15. Irradiance effect on generated Power ( $P_{\text {Float }}$ and $P_{G r o u n d}$ ).

Figure 16 displays the efficiency of floating PV panels and ground mounting. The efficiency is based on the ratio of $\mathrm{P}$ in and $\mathrm{P}$ (generated Power), where the pin is calculated by taking into account the irradiance achieved by the panel and the size of the panel surface. On average, the efficiency of floating PV panels is $4 \%$ higher than that of ground installation. Figure 16 shows how much the transition from sunny, cloudy, and rainy has an impact on efficiency. 


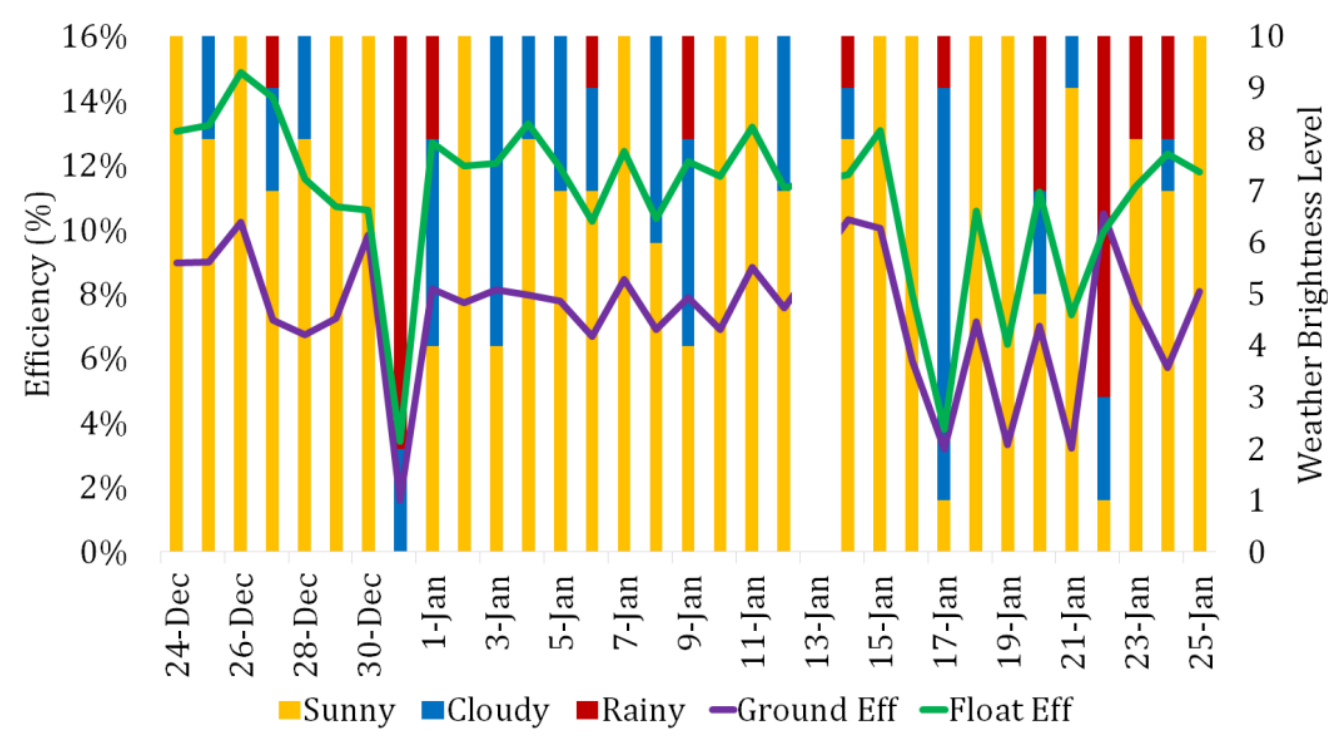

Figure 16. The comparison of efficiency between float and ground mounting.

This paper shows that the floating installation is more efficient and generates more power. Increased power and efficiency due to floating PV panel has a lower surface temperature compared to ground mounting. The effect of saltwater salinity on the performance of PV panels is not really demonstrated because the experiment is not long enough to achieve the effect. Another aim of this study is to demonstrate the results of the experiment conducted in [22], where salt accumulation on PV panels was achieved by spraying seawater on the PV panel surface for a month. This study needs to extend for a year to get the effects. The experiment results also show that PV panels can be installed over brackish waters in the fishing village of Sungsang Estuary.

\section{CONCLUSION}

The investigation conducted in this paper shows the feasibility of installing floating PV panels on Sungsang Estuary, South Sumatra. The floating PV panel has improved electrical properties, energy generation, and efficiency compared to the ground mounting. The difference between $I_{s c}$ floating and ground mounting is $0.4435 \mathrm{~A}$. The measured $I_{\text {load }}$ in floating PV panels is 0.3900 A higher then $I_{\text {load }}$ of ground mounting. The $V_{o c}$ measured at the floating PV panels is $0.2935 \mathrm{~V}$ higher than the ground mounting. The $V_{\text {load }}$ of the floating PV panel is $3.0742 \mathrm{~V}$ higher than ground mount. The electricity generated by floating PV panels is $11.89 \mathrm{~W}$ higher on average compared to the ground mounting. On average, the efficiency of floating PV panels is $4 \%$ higher than that of ground installation Unfortunately, the effect of salt sediment on the PV panel can not be demonstrated in this study, as it turned out that more time was required. 


\section{Acknowledgements}

The authors would like to thank the Technical Service and Maintenace Officer of PT PLN Sungsang ULP Mariana and PSDKP (Pengawasan Sumber Daya Kelautan dan Perikanan) Sungsang Officer for their support during this research. The authors also sincerely appreciate anonymous reviewers for valuable comments and suggestions.

\section{REFERENCES}

[1] IRENA, Renewable Energy Prospects: INDONESIA, 2017

[2] H.M. Yudha, Dewi, T. Dewi, P. Risma, Y. Oktarina, Life Cycle Analysis for the Feasibility of Photovoltaic System Application in Indonesia, Proceeding of International Conference on Science, Infrastructure Technology and Regional Development (ICoSITeR) 2017, Lampung, IOP Conference Series: Earth and Environmental Science, Vol. 124, 012005, 2018.

[3] Vinod, Raj Kumar, S.K. Singh, Solar Photovoltaic Modeling and Simulation: As a Renewable Energy Solution, Energy Report, Vol. 4, pp. 701-712, 2018.

[4] T. Dewi, P. Risma, Y. Oktarina, M.T. Roseno, H.M. Yudha, A.S. Handayani, Y. Wijanarko, A survey on Solar Cell; The Role of Solar Cell in Robotics and Robotic Application in Solar Cell Industry, Proceeding of Forum in Research, Science, and Technology (FIRST), 2016.

[5] T. Dewi, P. Risma, Y. Oktarina, A Review of Factors Affecting the Efficiency and Output of a PV system Applied in Tropical Climate, Proceeding of International Conference on Science, Infrastructure Technology and Regional Development (ICoSITeR) 2018, Lampung, the IOP Conference Series: Earth and Environmental Science, Vol. 258 $012039,2019$.

[6] P. Kamkird, N. Ketjoy, W. Rakwichian, S. Sukchai, Investigation on Temperature Coefficients of Three Types Photovoltaic Module Technologies under Thailand Operationg Condition, Procedia Engineering, Elsevier, Vol. 32, pp. 376-383, 2012.

[7] H. Li, J. Zhao, M. Li, S. Deng, Q. An, F. Wang, Performance Analysis of Passive Cooling for Photovoltaic Modules and Estimation of Energysaving Potential, Solar Energy, Vol. 181, pp. 70-82, 2019.

[8] H. A. Harahap, T. Dewi, Rusdianasari, Automatic Cooling System for Efficiency and Output Enhancement of a PV System Application in Palembang, Indonesia, Proceeding in 2nd Forum in Research, Science, and Technology, Journal of Physics: Conference Series, Vol. 1167, 2018

[9] D. Atsu, A. Dhaundiyal, Effect of Ambient Parameters on the Temperature Distribution of Photovoltaic (PV) Modules, Resources, MDPI, Vol. 8, No. 107, 12 pages, 2019.

[10] K. Chumpolrat, V. Sangsuwan, N. Udomdachanut, S. Kittisontirak, S. Songtrai, P. Chinnavornrungsee, A. Limmanee, J. Sritharathikhun, K. Sriprapha, Effect of Ambient Temperature on Performance of Grid- 
Connected Inverter Installed in Thailand, Hindawi Publishing Corporation, Vol. 2014, Article ID 502628, 6 pages, 2014.

[11] A. Duffie, W. A. Beckman, Solar Engineering of Thermal Processes, 1st Ed, John Wiley \& Sons, Inc., pp. 776-778, 2013.

[12] S. Krauter, A. Preiss, Comparison of Module Temperature Measurement Methods, Photovoltaik Institut Berlin AG.

[13] Y. Sun, S. Chen, L. Xie, R. Hong, H. Shen, Investigating the Impact of Shading Effect on the Characteristic of a Large-Scale Grid-Connected PV Power Plant in Northwest China, International Journal of Photoenergy, Hindawi Publishing Corporation, Vol. 2014, Article ID 763106, 9 pages, 2014.

[14] J.C. Teo, Rodney H.G. Tan, V. H. Mok, Vigna K. Ramachandaramurthy, ChiaKwang Tan, Impact of Partial Shading on the P-V Characteristic and the Maximum Power of Photovoltaic String, Energies, Vol. 11, No. 1860, 22 pages, 2018.

[15] A. Sahu, N. Yadav, K. Sudhakar, Floating Photovoltaic Power Plant: A Review, Renewable and Sustainable Energy Reviews, Vol. 66, pp. 815824, 2016.

[16] R. Cazzaniga, M. Rosa-Clot, P. Rosa-Clot, G. M. Tina, Integration of PV Floating with Hydroelectric Power Plants, Heliyon, Elsevier, Vol. 5, e01918, 2019.

[17] L. Liu, Q. Wang, H. Lin, H. Li, Q. Sun, R, Wennersten, Power Generation Efficiency and Prospects of Floating Photovoltaic System, Proceeding of The $8^{\text {th }}$ International Conference on Applied Energy (ICAE2018), Beijing, Energy Procedia, Vol. 105, pp. 1136-1142, 2017.

[18] M. Abid, Z. Abid, J. Sagin, R. Murtaza, D. Sarbassov, M. Shabbir, Prospects of floating photovoltaic technology and its implementation in Central and South Asian Countries, International Journal of Environmental Science and Technology, Springer, Vol. 16, pp. 17551762, 2018.

[19] M. Perez, R. Perez, C. R. Ferguson, J. Schlemmer, Deploying Effectively Dispatchable PV on Reservoirs: Comparing Floating PV to Other Renewable Technology, Solar Energy, Vol. 174, pp. 837-847, 2018.

[20] Todd R. Sandrin, Scot E. Dowd, David C. Herman, Raina M. Maier, Chapter 6. - Aquatic Environment, Environmental Microbiology, Elsevier, Ed. 2, pp. 103-122, 2009.

[21] Fauziah, Nurhayati, S. M. Bernas, A. Putera, Y. Suteja, F. Agustini, Biodiversity of Fish Resources in Sungsang Estuaries of South Sumatera, Proceeding of The 3rd EMBRIO International Workshop on Marine Biodiversity: Understanding, Utilization, Bogor, Vol. 278, 11 pages, 2019.

[22] F. Setiawan, T. Dewi, and S. Yusi, Sea Salt Deposition Effect on Output and Efficiency Losses of the Photovoltaic System; a Case Study in Palembang, Indonesia, Proceeding in 2nd Forum in Research, Science, and Technology, Journal of Physics: Conference Series, Vol. 1167, 2018. 